\title{
Environmental variables controlling soil respiration on diurnal, seasonal and annual time-scales in a mixed mountain forest in Switzerland
}

\author{
Nadine K. Ruehr • Alexander Knohl • \\ Nina Buchmann
}

Received: 25 January 2009/ Accepted: 24 September 2009/Published online: 15 October 2009

(C) Springer Science+Business Media B.V. 2009

\begin{abstract}
Studies on soil respiration in mountain forests are rather scarce compared to their broad distribution. Therefore, we investigated daily, seasonal and annual soil respiration rates in a mixed forest (Lägeren), located at about $700 \mathrm{~m}$ in the Swiss Jura mountains, during 2 years (2006 and 2007). Soil respiration (SR) was measured continuously with high temporal resolution (half-hourly) at one single point ( $\left.\mathrm{SR}_{\text {automated }}\right)$ and periodically with high spatial resolution $\left(\mathrm{SR}_{\text {manual }}\right)$ at 16 plots within the study site. Both, $\mathrm{SR}_{\text {automated }}$ and $\mathrm{SR}_{\text {manual }}$ showed a similar seasonal cycle. SR strongly depended on soil temperature in $2007\left(R^{2}=0.82-0.92\right)$, but less so in $2006\left(R^{2}=0.56-0.76\right)$ when SR was water limited during a summer drought. Including soil moisture improved the fit of the 2006 model significantly $\left(R^{2}=0.78-0.97\right)$. Total annual SR for the study site was estimated as $869 \mathrm{~g} \mathrm{C} \mathrm{m}^{-2}$ year $^{-1}$ for 2006 and as $907 \mathrm{~g} \mathrm{C} \mathrm{m}^{-2}$ year $^{-1}$ for 2007 (uncertainty $<10 \%$ at the $95 \%$ confidence interval, determined by bootstrapping). Selected environmental conditions were assessed in more detail: (1) Rapid, but contrasting
\end{abstract}

N. K. Ruehr $(\bowtie) \cdot$ A. Knohl · N. Buchmann Institute of Plant Science, ETH Zurich, Universitaetstrasse 2, LFW, 8092 Zurich, Switzerland e-mail: nadine.ruehr@ipw.agrl.ethz.ch

Present Address:

A. Knohl

Division of Bioclimatology, Georg-August University of Göttingen, Büsgenweg 2, 37073 Göttingen, Germany changes of SR were found after summer rainfall. Depending on soil moisture at pre-rain conditions, summer rain could either cause a pulse of $\mathrm{CO}_{2}$ from the soil or an abrupt decrease of $\mathrm{SR}_{\text {automated due to }}$ water logging of soil pores. (2) Two contrasting winter seasons resulted in SR being about 60-70\% (31.2-44.6 $\mathrm{g} \mathrm{C} \mathrm{m}^{-2}$ ) higher during a mild winter (2007) compared to a harsh winter (2006). (3) Analysing SR for selected periods on a diurnal scale revealed a counter-clockwise hysteresis with soil surface temperatures. This indication of a time-lagged response of SR to temperature was further supported by a very strong relationship $\left(R^{2}=0.86-0.90\right)$ of SR to soil temperature with a time-lag of $2-4 \mathrm{~h}$.

Keywords $\mathrm{CO}_{2}$ pulse Drought . Soil $\mathrm{CO}_{2}$ efflux . Temperate forest . Time lag $\cdot$ Winter respiration

\section{Introduction}

Soil respiration, the component flux of root-rhizosphere and soil microbial respiration, is the most important process of carbon loss from terrestrial ecosystems. On average, soil respiration (SR) can attribute about $70 \%$ to total ecosystem respiration in temperate forests (Janssens et al. 2001). Thus, changes in SR can strongly influence net ecosystem exchange (NEE), i.e., the balance between gross primary productivity (GPP) and ecosystem respiration 
(Valentini et al. 2000). Higher temperatures as predicted for the next decades (IPCC 2007) could increase root-rhizosphere respiration rates (Burton et al. 2008) and, of major concern, could lead to faster microbial decomposition rates of soil organic matter and thus to a positive feedback on global warming (Jenkinson et al. 1991; Davidson et al. 2000; Knorr et al. 2005; Davidson and Janssens 2006; Heimann and Reichstein 2008). However, this is still an ongoing discussion (Davidson and Janssens 2006, as other studies did not find such a clear trend of decomposition rates with mean annual temperatures (Liski et al. 1999; Giardina and Ryan 2000).

To date, SR, the second largest carbon flux in terrestrial ecosystems after GPP, has been studied in many ecosystems all over the world (Schlesinger and Andrews 2000), often in forests (e.g., Janssens et al. 2001), but mostly focusing on rather flat terrain (e.g., Longdoz et al. 2000; Pilegaard et al. 2001). However, in Switzerland, the majority of forests are located on mountainous areas, with almost half of the forests $(48 \%)$ on slopes being steeper than $22^{\circ}$ (Brassel and Bräandli 1999). Despite covering about one-forth of the forest land globally (about 9.5 million $\mathrm{km}^{2}$; UNEP-WCMC 2000), our knowledge of the magnitudes of SR fluxes in such mountain forests is rather limited. Furthermore, most often, SR measurements on mountain forest slopes are limited to the growing season (e.g., Hanson et al. 1993; Kang et al. 2003), often neglecting non-growing season fluxes. This is even more surprising, since winter soil respiration can lead to significant carbon losses from forest ecosystems, accounting for 10-20\% of annual SR estimates (Zimov et al. 1996; Mast et al. 1998; Mariko et al. 2000; McDowell et al. 2000; Schindlbacher et al. 2007). Therefore, winter soil respiration can be an important factor in determining NEE, particularly in mountain forests with a pronounced snow cover (e.g., Monson et al. 2006).

Providing SR fluxes and assessing their response to climate change in any terrestrial ecosystem requires both high temporal resolution as well as spatially representative measurements over several seasons. Nowadays, these requirements are typically achieved by SR being measured either continuously with high time resolution (e.g., half-hourly) or periodically (e.g., bi-weekly) but at high spatial resolution. The calculation of annual estimates of SR linked to Eddy Covariance (EC) measurements of net ecosystem $\mathrm{CO}_{2}$ exchange is then done using a sitespecific model, summing up modeled half-hourly or daily SR rates (e.g., Knohl et al. 2008). However, such an approach based on periodically measured SR might be biased. If measurements are not carried out frequently enough, extreme weather events might be missed or longer-lasting events such as drought undersampled and therefore not accounted properly in the respective model, resulting in under- or overestimated annual SR totals. Therefore, the combined use of continuous chamber measurements of SR with manual periodic measurements at many locations has been discussed as most beneficial, providing the most detailed picture of the response of soil respiration to environmental changes (Savage and Davidson 2003) and being the most reliable approach to gain annual SR totals. Nevertheless, studies using this combined approach to address SR in temperate mountain forests are still scarce.

Therefore, our aims were to determine the annual carbon dioxide loss from soils and to identify its dominant drivers at different temporal scales, from hourly to seasonal to interannual scales in a mixed mountain forest in Switzerland. We used a combined measurement approach with SR measured periodically at 16 plots and SR measured continuously at one single location within the footprint of an EC tower on a South-facing slope in the Swiss Jura during 2 years.

\section{Methods}

Study site and experimental setup

The CarboEurope forest flux site Lägeren (CH-LAE, $47^{\circ} 28^{\prime} 42.0^{\prime \prime} \mathrm{N} ; 8^{\circ} 21^{\prime} 51.8^{\prime \prime} \mathrm{E}$ ) is situated $20 \mathrm{~km}$ NorthWest of Zurich, Switzerland, at a mean altitude of about $700 \mathrm{~m}$ a.s.l. on the South-facing slope of the Lägeren mountain (866 $\mathrm{m}$ a.s.l.), part of the Swiss Jura. The study site with an altitudinal gradient of about $100 \mathrm{~m}$ and an average slope of $24^{\circ}(45 \%)$, ranging between $10^{\circ}$ and $45^{\circ}$, extends $200 \mathrm{~m}$ West and East, and $150 \mathrm{~m}$ North and South of the Lägeren EC tower and thus covers a representative area of the EC footprint (Fig. 1). The upper slope of the study site is a nature reserve and comprises a mixed beech forest unmanaged since 1998, while the lower slope is still an extensively managed forest according to 


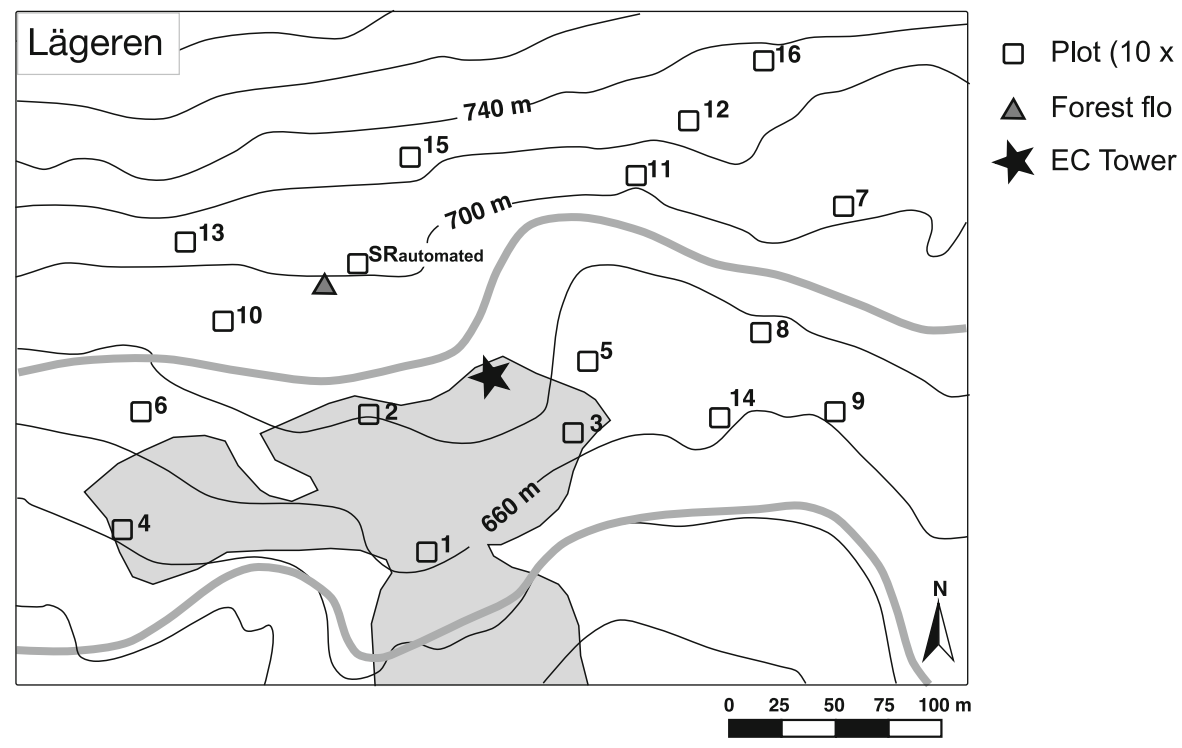

Fig. 1 Map of the Lägeren study site fully covered by forest. The locations of the plots are shown where $\mathrm{SR}_{\text {manual }}$ was measured bi-weekly. Plots can be identified by their numbers (see also Table 3). Continuous soil moisture was measured at the forest floor station. Air temperature and precipitation were

FSC (Forest Stewardship Council) rules. The vegetation of the whole study site is typical for a highly diverse mixed mountain forest. The overstory vegetation consists mainly of beech, ash, fir, lime and spruce trees (Fagus sylvatica L., Fraxinus excelsior L., Abies alba Mill., Tilia cordata Mill., Picea abies (L.) Karst., respectively). These species represent over $80 \%$ of the basal area with Quercus robur L., Acer pseudoplatanus L., Acer platanoides L., Carpinus betulus L. and Ulmus glabra Huds. interspersed. The maximum leaf area index (LAI) of the overstory vegetation varied in the study site from 1.7 to $5.5 \mathrm{~m}^{-2}$ over the growing seasons of the 2 years 2006 and 2007. Generally, the understory vegetation is scarce and consists mainly of Allium ursinum L. flowering in early spring, except for those areas that were strongly affected by a winter storm in 1999 , having an often dense understory of blackberry and raspberry as well as of juvenile beech and ash trees (about $15 \%$ of the study site; Fig. 1).

The main bedrocks of the study site are limestone, marl and sandstone, with transition zones between marl and limestone (loamy debris) and marl mixed with sandstone (loam). The main soil types are rendzic leptosols (or rendzinas) and haplic cambisols according to the World Reference Base of Soil Resources measured at the EC tower. Unpaved forest roads are represented by the thick grey lines. The grey colored area shows the part of the study site most affected by a winter storm in 1999 (80\% of the trees were thrown)

(IUSS Working Group WRB 2007). Since leaf litter decomposes almost completely within 1 year, the litter layer is distinct after autumn leaf litter fall (c. $4 \mathrm{~cm}$ ) and decreases steadily to the end of summer $(<1 \mathrm{~cm})$. The rendzina soils have higher carbon $\left(6.5 \mathrm{~kg} \mathrm{C} \mathrm{m}^{-2}\right)$ and nitrogen $\left(0.47 \mathrm{~kg} \mathrm{~N} \mathrm{~m}^{-2}\right)$ stocks in the upper $10 \mathrm{~cm}$ compared to the cambisol soils (3.9 $\mathrm{kg} \mathrm{C} \mathrm{m}^{-2}, 0.3 \mathrm{~kg} \mathrm{~N} \mathrm{~m}^{-2}$; Heim et al. 2009; Wehrli, unpublished). Since the study site is rather heterogeneous, 17 plots $(10 \mathrm{~m} \times 10 \mathrm{~m}$, at least $25 \mathrm{~m}$ apart from each other) were established, accounting for the two main soil types and associated vegetation characteristics, to ensure representativeness of the plots in the study area (Fig. 1). One litter trap of $1 \mathrm{~m}^{2}$ was placed in each of the 17 plots in October 2005 within $2 \mathrm{~m}$ distance to the collars for SR measurements (see below). The traps were emptied monthly from October 2005 to January 2008, except during autumn sampling was intensified on a bi-weekly basis. Litter was sorted into leaves, wood and reproductive organs, dried $\left(48 \mathrm{~h}\right.$ at $\left.65^{\circ} \mathrm{C}\right)$ and weighed. Continuous air temperature and precipitation data were available from the Swiss National Air Pollution Monitoring Network (NABEL), measured at the Lägeren EC tower. Mean annual air temperature during the two years of the study was $8.9^{\circ} \mathrm{C}$ in 2006 and $9.1^{\circ} \mathrm{C}$ 
in 2007. Annual precipitation was higher in 2006 (1,032 mm) compared to 2007 (914 mm).

Automated soil respiration measurements (SR automated $)$

Automated soil respiration ( $\left.\mathrm{SR}_{\text {automated }}\right)$ was measured during 2006 and 2007 on a half-hourly basis, in one of the plots about $50 \mathrm{~m}$ North-East from the Lägeren EC tower (Fig. 1), with first measurements 2 weeks after collar installation $(20.3 \mathrm{~cm}$ inside diameter, $11 \mathrm{~cm}$ high, PVC). A closed system (LI8100, Li-Cor inc, Lincoln, NE, USA), permanently connected to a chamber (Li-8100-101, Li-Cor inc, Lincoln, NE, USA) was used, opening in a $180^{\circ}$ vertical arc to allow the soil to be exposed most of the time to ambient environmental conditions. To prevent shadow on the collar as well as precipitation exclusion on the uphill side, the open chamber was oriented to the North-East. The length of one measurement varied over the seasons: for high $\mathrm{CO}_{2}$ efflux rates, measurement time was set to $60 \mathrm{~s}$, for low $\mathrm{CO}_{2}$ efflux rates, measurement time was expanded to $120 \mathrm{~s}$. Soil temperatures (HTT thermocouple, OMEGA Engineering, Inc., Stamford, CT, USA) at 1, 5 and $10 \mathrm{~cm}$ depth, as well as soil moisture at $10 \mathrm{~cm}$ depth (EC-20, Decagon Devices Inc., Pullman, WA, USA) were logged at the same time intervals.

The zero and span gases for $\mathrm{CO}_{2}$ and $\mathrm{H}_{2} \mathrm{O}$ of the automated and the manual soil respiration systems were calibrated on an annual basis, since both $\mathrm{CO}_{2}$ and $\mathrm{H}_{2} \mathrm{O}$ zero and span calibrations showed only minor changes (drift of $\mathrm{CO}_{2}$ span: $0.03-0.46 \%$ at $567.5 \mathrm{ppm}$ ) after 1 year, no data correction was applied. Data coverage of $\mathrm{SR}_{\text {automated }}$ was about $70 \%$ in both years; in total 24,479 half-hourly measurements were included in the analysis. Data gaps occurred mostly due to equipment or power failure and after heavy snowfall when snow cover was $>10 \mathrm{~cm}$ (lid of the LI8100-103 did not close). In June 2006, soil cracks developed which unsealed the collar from the soil; thus, $\mathrm{SR}_{\text {automated }}$ data were rejected, and a new collar was installed close-by (within $50 \mathrm{~cm}$ ).

\section{Manual soil respiration measurements $\left(\mathrm{SR}_{\text {manual }}\right)$}

In the center of each of the 16 plots, we installed one collar, at a location without vegetation (vegetation within the collars was removed regularly), in average about $3 \mathrm{~m}$ away from the nearest tree (diameter breast hight $>10 \mathrm{~cm}$ ), 2 weeks prior to the measurements. The PVC collars (inside diameter of $19.6 \mathrm{~cm}$, $10 \mathrm{~cm}$ high) were inserted about $1.5 \mathrm{~cm}$ into in the soil and additionally clamped with $10 \mathrm{~cm}$ long tent pegs to guarantee stability also at steep slopes. $\mathrm{SR}_{\text {manual }}$ was measured campaign-wise at all 16 plots every two to 3 weeks during 2006 and 2007, using a closed chamber system with a portable, non-dispersive infrared gas analyzer (LI-8100 with LI-8100-103 chamber, Li-Cor inc, Lincoln, NE, USA; except for measurements in January and February 2006 that were conducted with a LI-6400 with soil collars that were $10 \mathrm{~cm}$ in diameter and $10 \mathrm{~cm}$ high). During January 2006, only 11 plots could be measured due to ice on the steep slopes.

For each collar, soil respiration were measured twice; each measurement lasted on average about $90 \mathrm{~s}$, separated by $60 \mathrm{~s}$ between repeated measurements, during which the chamber opened and closed automatically, to achieve ambient $\mathrm{CO}_{2}$ concentrations. For later data analysis, $\mathrm{SR}_{\text {manual }}$ data was rejected if the coefficient of variation between the repeated measurements was $>25 \%$. In each plot, next to the SR collar, soil temperature sensors (HOBO Pendant Temperature Data Logger, Onset Computer Corporation, Bourne, MA, USA) were installed at $5 \mathrm{~cm}$ depth, which logged soil temperature every $30 \mathrm{~min}$. All manual soil respiration measurements $\left(\mathrm{SR}_{\text {manual }}\right)$ were accompanied by periodical measurements of volumetric soil moisture at $6 \mathrm{~cm}$ depth (ML2X Theta Probe, Delta-T Devices, Cambridge, UK). These soil moisture measurements closely followed the seasonal pattern of continuous soil moisture measurements $(10 \mathrm{~cm}$ depth; EC-20, Decagon Devices Inc., Pullman, WA, USA) at the forest floor station (Fig. 1). Thus, for later data analysis, only soil moisture measurements from the forest floor station, synchronized with SR measurements, were used.

During each $\mathrm{SR}_{\text {manual }}$ campaign, which lasted on average from 10 to $16 \mathrm{~h}$, plots were measured in a different order to prevent confounding effects by diurnal trends. Further, potential methodological bias of the $\mathrm{SR}_{\text {manual }}$ campaigns could result from the time of the measurements, therefore, we compared halfhourly $\mathrm{SR}_{\text {automated }}$ rates measured at the campaign days during $10-16 \mathrm{~h}$ to $\mathrm{SR}_{\text {automated }}$ rates measured before $10 \mathrm{~h}$ and after $16 \mathrm{~h}$ at the same days. However, we found no significant differences between the 
means of $\mathrm{SR}_{\text {automated }}$ during versus before/after the $\mathrm{SR}_{\text {manual }}$ campaigns (paired $t$ test: 2006, $P=$ $0.60, n=16 ; 2007, P=0.82, n=13$ ). As a control for the representativeness of the measured flux rates at one fixed location (collar) per plot, we installed one additional collar at a random location within each plot. These collars were measured less frequently (c. every 2 months) and displaced after each measurement within each plot. Comparing the campaignaverages of $\mathrm{SR}_{\text {manual }}$ of fixed with those of randomly displaced collars, showed a strong agreement, near the one-to-one line $(\mathrm{rsq}=0.93, P<0.001 ;$ Fig. 2$)$. Using a power function (see Davidson et al. 2002; Knohl et al. 2008) revealed that the campaign-averages of $\mathrm{SR}_{\text {manual }}$ were within $10-20 \%$ precision at a $95 \%$ confidence interval. On this basis, we considered the $\mathrm{SR}_{\text {manual }}$ measurements as being representative for the study site.

\section{Soil respiration models}

Soil respiration rates were related to soil temperature using a non-linear least squares model (model $\mathrm{SR}_{\mathrm{m}}$, 1), after Lloyd and Taylor (1994):

$\mathrm{SR}_{\mathrm{m}, 1}=R_{\mathrm{ref}} \mathrm{e}^{E_{0}\left(\frac{1}{T_{\text {ref }}-T_{0}}-\frac{1}{T_{\text {soil }}-T_{0}}\right)}$

where $R_{\text {ref }}$ is soil respiration $\left(\mu \mathrm{mol} \mathrm{CO}_{2} \mathrm{~m}^{-2} \mathrm{~s}^{-1}\right.$ ) under standard conditions (at $T_{\text {ref }}=10^{\circ} \mathrm{C}$; about equal to mean annual soil temperature in $5 \mathrm{~cm}$ depth),

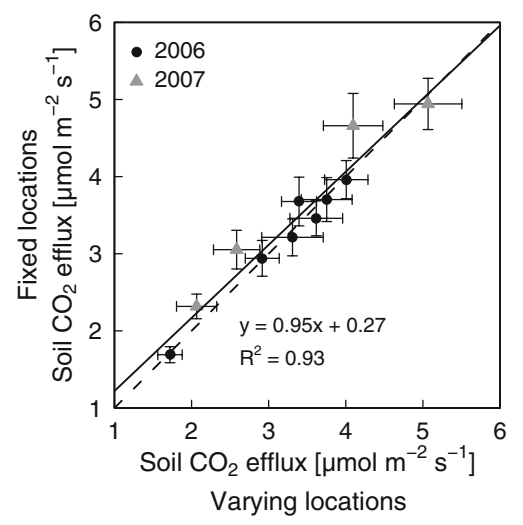

Fig. 2 Campaign-averages of $\mathrm{SR}_{\text {manual }}$ from fixed locations $(n=16)$ versus soil respiration from varying locations ( $n=16$ ) all measured within the 16 plots of the study. The linear relationship is shown by the solid black line, the dashed black line indicates the ideal one-to-one line. Bars are $\pm 1 \mathrm{SE}$ of the means
$E_{0}\left(\mathrm{~K}^{-1}\right)$ is the parameter for activation energy, $T_{0}$ $=-46.02^{\circ} \mathrm{C}$, as in the original Lloyd and Taylor model and $T_{\text {soil }}$ is the measured soil temperature at a given depth.

When SR was limited by water availability, as in summer 2006, the temperature sensitivity of SR depended on soil moisture and, therefore, a second model $\left(\mathrm{SR}_{\mathrm{m}, 2}\right)$ was used, in which $E_{0}$ was defined as a linear function of soil moisture (Reichstein et al. 2003):

$\mathrm{SR}_{\mathrm{m}, 2}=R_{\mathrm{ref}} \mathrm{e}^{(a S M+b)\left(\frac{1}{T_{\text {ref }}-T_{0}}-\frac{1}{T_{\text {soil }}-T_{0}}\right)}$

with $S M$ being the measured volumetric soil moisture at a given depth, and $a$ and $b$ are the parameters of the linear function. The coefficient of determination $\left(R^{2}\right)$ for all non-linear least squares models was calculated as:

$R^{2}=1-\left(\frac{\text { Residual } \mathrm{SS}}{\text { Total } \mathrm{SS}}\right)$

whereby SS are the sums of squares. Although the theory of $R^{2}$ does not totally hold for non-linear least squared models (the residuals of non-linear least squares models do not sum up to zero; if the model totally fails, $R^{2}$ can be negative), we provide the $R^{2}$ value as an indicator for the goodness of fit for the models (Kvalseth 1985).

Annual SR estimates and uncertainties

To assess the uncertainties of modeled seasonal and annual SR estimates, caused by temporal and spatial integration, Monte Carlo simulations (parametric bootstrapping) were applied (Knohl et al. 2008). To estimate annual $\mathrm{SR}_{\text {manual }}$ for each plot in 2006, we first calculated the parameters $R_{\text {ref }}, a$ and $b$ from Eq. 2 with their respective standard deviations, using $\mathrm{SR}_{\text {manual }}$ (each plot) and continuous soil temperature (5 cm depth; each plot) and soil moisture $(10 \mathrm{~cm}$ depth; forest floor station) measured at the same time. Then, 5,000 annual sums of $\mathrm{SR}_{\text {manual }}$ were calculated based on continuous soil temperature and moisture measurements for each plot by sampling 5,000 times triplets of the regression parameters $\left(R_{\mathrm{ref}}, a, b\right)$ with replacement from a trivariate normal distribution, defined by the regression parameters and the standard deviations. Based on the distribution of annual sums 
obtained from these 5,000 samplings, we calculated the mean and 95\%-confidence interval for the annual sums for each plot. To estimate the annual $\mathrm{SR}_{\text {manual }}$ for each plot in 2007, we followed the same procedure. First, we fitted the parameters $R_{\text {ref }}$ and $E_{0}$ in Eq. 1 using $\mathrm{SR}_{\text {manual }}$ and synchronized soil temperature $(5 \mathrm{~cm}$ depth; each plot) measurements. Then, 5,000 annual sums of $\mathrm{SR}_{\text {manual }}$ were calculated based on continuous soil temperature measurements for each plot by sampling 5,000 times pairs of the regression parameters $\left(R_{\text {ref }}, E_{0}\right)$ with replacement from a bivariate normal distribution, defined by the regression parameters and their standard deviations. To obtain the total mean and confidence interval across several plots (e.g, for the whole study site), we averaged the annual sums from each single of these 5,000 samplings across all plots and reported the mean and $95 \%$ confidence interval of these annual $\mathrm{SR}_{\text {manual }}$ rates.

To gain annual or seasonal estimates for $\mathrm{SR}_{\text {auto- }}$ mated, we had to gap-fill the data. First, we divided each year into a growing season (1 April to $31 \mathrm{Oct})$ and a dormant season (1 Jan to 31 March and $1 \mathrm{Nov}$ to $31 \mathrm{Dec})$, because parameters of the Lloyd and Taylor model may change between seasons (Janssens and Pilegaard 2003). Then, we calculated the parameters of the models (Eqs. 1 and 2) with their respective standard deviations using $\mathrm{SR}_{\text {automated }}$ with synchronized soil temperature $(5 \mathrm{~cm} \mathrm{depth})$ and, if Eq. 2 was used, soil moisture measurements $(10 \mathrm{~cm}$ depth). To estimate annual and seasonal sums as well as their uncertainties, we used Monte Carlo simulations, described above for the $\mathrm{SR}_{\text {manual }}$ measurements. However, uncertainties were estimated only when missing data was replaced by modeled data.

Furthermore, we analysed the influence of autocorrelation of the residual error on annual (seasonal) sums and uncertainties by recalculating all annual sums assuming no (0) and high (0.9) autocorrelation. Even if with the assumption of high (0.9) autocorrelation the effect on the annual sums and uncertainties was negligible $(1 \%)$ similar as reported by Knohl et al. (2008). Hence, here we report conservative estimates of annual and seasonal SR sums and their uncertainties for $\mathrm{SR}_{\text {automated, }}$ presuming high autocorrelation of the residual error. All statistical calculations were performed using R version 2.6.1 (R Development Core Team 2007), extended by the MASS package for parametric bootstrapping (Venables and Ripley 2002).

\section{Results}

Seasonal course of soil respiration

The seasonal course of air and soil temperatures was very pronounced at our study site with lowest temperatures in January and highest temperatures in July in 2006 and 2007 (Fig. 3a, b, e, f). However, both years showed contrasting annual precipitation patterns. Spring 2006 was rather moist compared to a much drier spring 2007, while summer 2006 (JuneJuly) was dry compared to a moist summer in 2007 (Fig. 3a, b). The SR rates measured over the 2 years showed a strong seasonal course, following changes in soil temperature (Fig. 3c, d). Using the manual approach of measuring soil respiration $\left(\mathrm{SR}_{\text {manual }}\right)$ to characterize the spatial heterogeneity within the study site, resulted in a minimum campaign-average of $0.41 \mu \mathrm{mol} \mathrm{CO}_{2} \mathrm{~m}^{-2} \mathrm{~s}^{-1}$ at 1 February 2006 and a maximum campaign-average of $4.74 \mu \mathrm{mol} \quad \mathrm{CO}_{2}$ $\mathrm{m}^{-2} \mathrm{~s}^{-1}$ at 17 July 2007. In addition, using the automated approach to capture the temporal variation at one location ( $\mathrm{SR}_{\text {automated }}$ ), showed a minimum daily average of $0.30 \mu \mathrm{mol} \mathrm{CO}_{2} \mathrm{~m}^{-2} \mathrm{~s}^{-1}$ at 21 January 2006 and a maximum daily average of $5.71 \mu \mathrm{mol} \mathrm{CO} \mathrm{CO}^{-2} \mathrm{~s}^{-1}$ at 5 September 2006. Thus, SR measured with both approaches showed the same seasonal pattern (Fig. 3c, d), with the means of $\mathrm{SR}_{\text {automated }}$ being within the range observed for the $\mathrm{SR}_{\text {manual }}$ measurements.

Soil respiration was typically very strongly related to soil temperature at $5 \mathrm{~cm}$ depth (Fig. 4). However, low precipitation (only $82.4 \mathrm{~mm}$ in June and July 2006, Fig. 3a) and a decline of soil moisture to a minimum of about $11 \%$ (about $40 \%$ relative soil water content, Reichstein et al. 2003) caused a strong water limitation on soil respiration. The threshold for this water limitation was at about $15 \%$ soil moisture content (about $55 \%$ relative soil water content; Fig. $4 a-c)$. In 2006, soil temperature alone explained $76 \%$ of campaign-averages of $\mathrm{SR}_{\text {manual }}$ (Eq. 1, $\mathrm{SR}_{\text {manual }}: R^{2}=0.76, P<0.001, n=20 ; \mathrm{SR}_{\text {automated }}$ : $\left.R^{2}=0.56, P<0.001, n=12142\right)$. Thus, taking this water limitation threshold into account and including soil moisture improved the explained annual variation of all campaign-averages of $\mathrm{SR}_{\text {manual }}$ in 2006 tremendously (Eq. 2, SR manual $^{2}=0.97, P<0.001, n=$ 20; $\mathrm{SR}_{\text {automated }}: R^{2}=0.78, P<0.001, n=12142$ ). In 2007 , SR was strongly related to soil temperature 


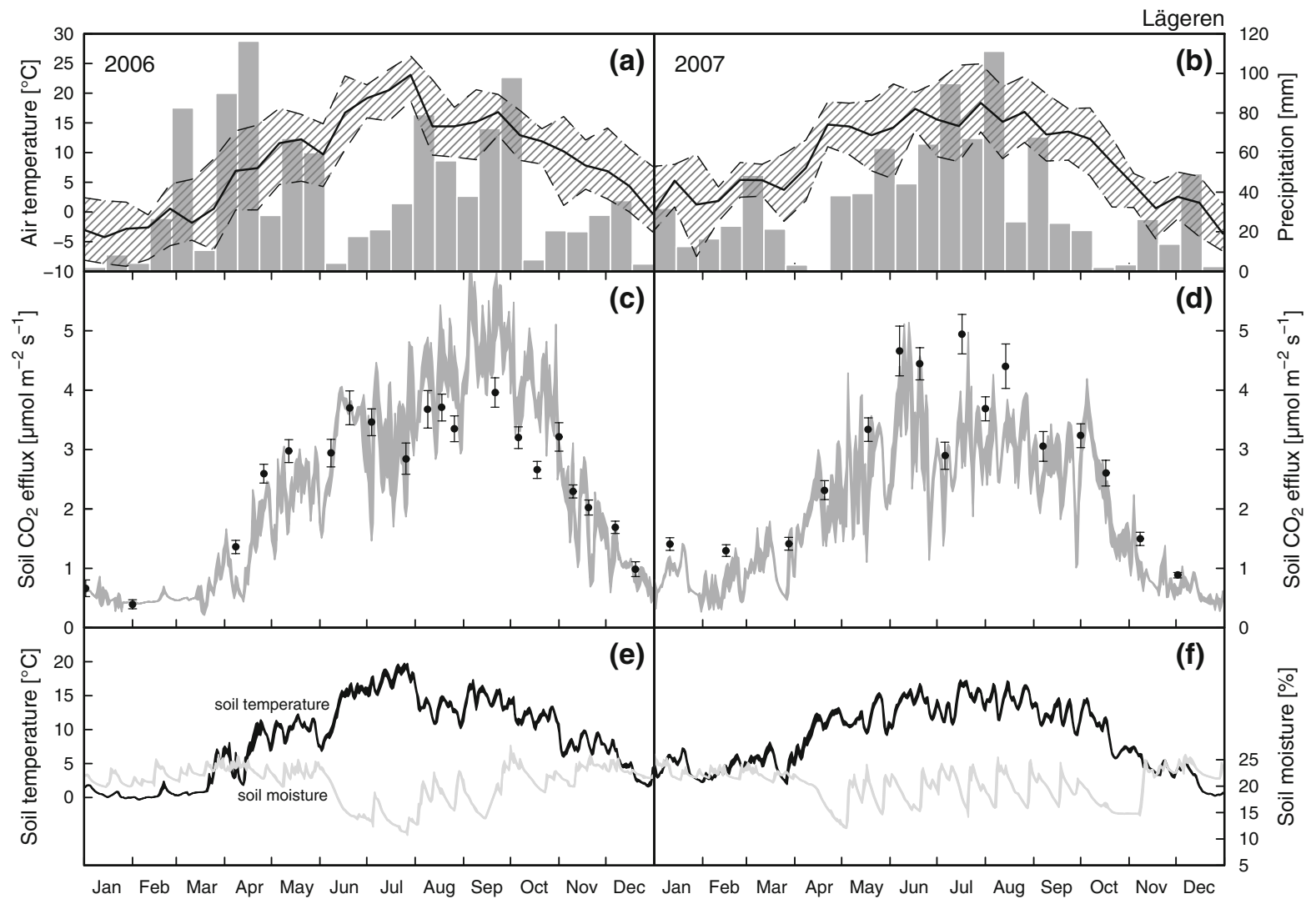

Fig. 3 Time-series of air temperature, precipitation, $\mathrm{SR}_{\text {auto- }}$ mated, $\mathrm{SR}_{\text {manual, }}$, soil temperature and soil moisture for 2006 and 2007. a, b: air temperature averaged over 14 days is represented by the solid black line. The striped area shows the air temperature range within 14 days maximum and minimum represented by the dashed black lines. Precipitation summed over 14 days is shown by the grey barplots. c, d:

$\left(\mathrm{SR}_{\text {manual }}: R^{2}=0.92, P<0.001, n=20 ; \mathrm{SR}_{\text {automated }}\right.$ : $R^{2}=0.82, P<0.001, n=12337$; Fig. $4 \mathrm{~b}$ and $\mathrm{f}$, respectively). Even though precipitation in April 2007 was $<1 \mathrm{~mm}$ and soil moisture declined from $22 \%$ to about $13 \%$ (Fig. 3b, f), no water limitation on SR could be detected in 2007 .

As for the data over the entire year, the dependence of half-hourly $\mathrm{SR}_{\text {automated }}$ rates on soil temperature was also strong during dormant seasons, while it was less pronounced during growing seasons of both years (Table 1). In 2006, the temperature relationship of SR was particularly weak during the growing season (Eq. 1, $R^{2}=0.29, \quad P<0.001$, $n=8436$ ), but could be substantially improved including soil moisture (Eq. 2), resulting in 59\% of the variation of half-hourly $\mathrm{SR}_{\text {automated }}$ rates being campaign-averages of $\mathrm{SR}_{\text {manual }}$ are represented by the black dots and bars ( $\pm 1 \mathrm{SE})$. Daily means of $\mathrm{SR}_{\text {automated with }}$ standard deviations are represented by the thick grey line. Missing $\mathrm{SR}_{\text {automated }}$ data was modeled using Eqs. 1 and 2 (see Table 1). e, f: daily means of soil temperature $(5 \mathrm{~cm}$ depth) and soil moisture $(10 \mathrm{~cm}$ depth) are shown with their respective standard deviations.

explained (Table 1). During the growing season in 2007 , only $50 \%$ of the variation of $\mathrm{SR}_{\text {automated }}$ could be explained by soil temperature, but including soil moisture did not improve the model either.

Impact of rain events on SR in two contrasting summers

The two years of the study differed substantially in summer weather conditions. While 2006 was characterized by a drought with only $255.5 \mathrm{~mm}$ rain during June-August, 2007 was rather wet with $477.5 \mathrm{~mm}$ rain during June-August (Fig. 3a, b). This offered the opportunity to study responses of SR to rain events. During the drought spell in July 2006, when SR was water limited and soil moisture was at $13 \%$, a strong 
Fig. 4 Relationships between soil respiration and soil temperature $(5 \mathrm{~cm}$ depth) for 2006 and 2007. The Lloyd and Taylor model (Eq. 1) and the $R^{2}$ are given for soil respiration versus soil temperature (in $\mathbf{a}, \mathbf{c}$ and $\mathbf{e}$ only if soil moisture $\geq 15 \%$ ) with the best fit indicated by the solid lines. The inserted smaller panels show the deviation from the best fit of the model versus soil moisture. a, b: Campaignaverages of $\mathrm{SR}_{\text {manual, }}$ bars indicate \pm 1 SE. c, d: dailyaverages of $\mathrm{SR}_{\text {automated }} ; \mathbf{e}, \mathbf{f}$ : half-hourly rates of $\mathrm{SR}_{\text {automated }}$

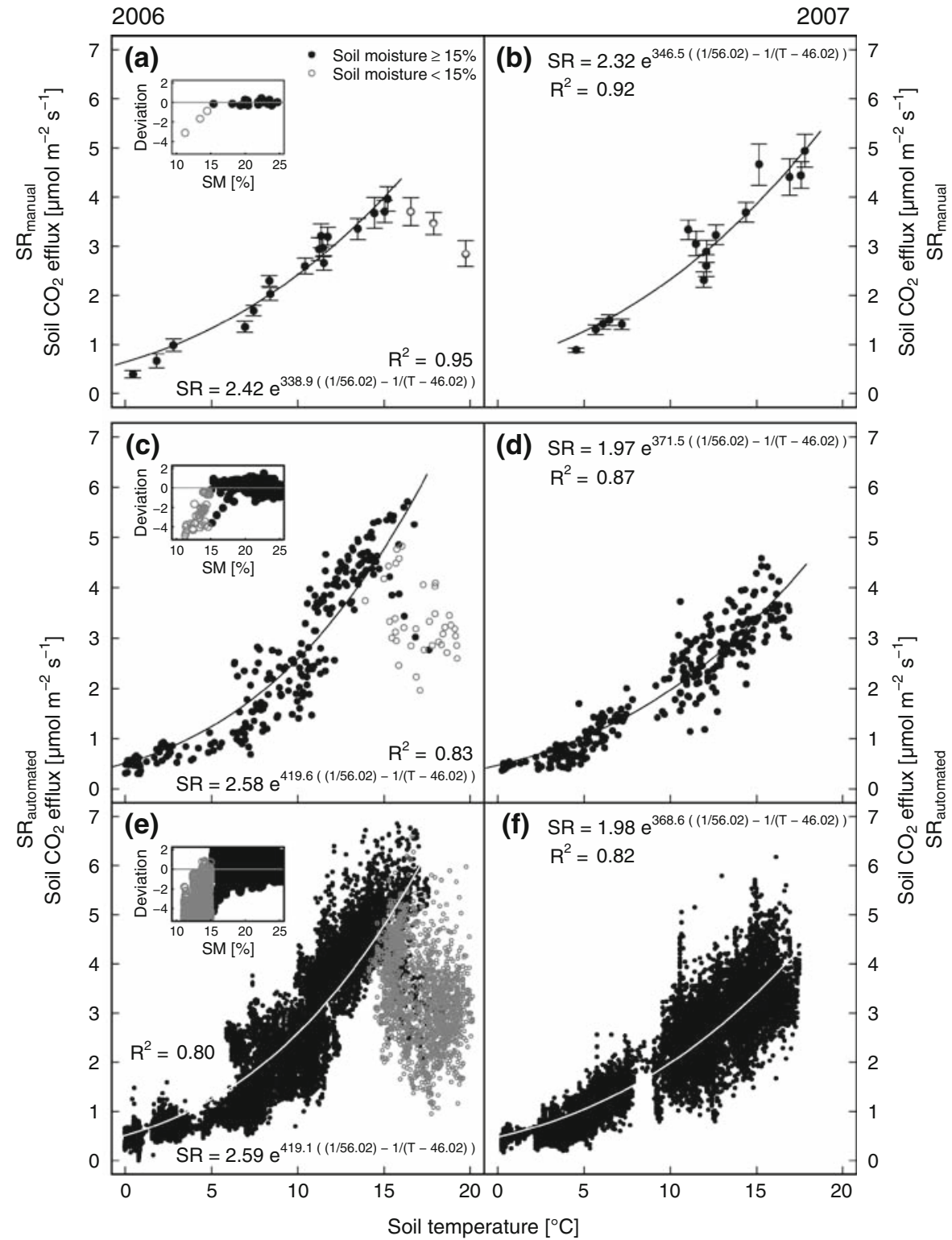

Table 1 Model parameters to gap fill SR automated for dormant (1 Jan to 31 March and 1 Nov to 31 Dec) and growing seasons (1 April to $31 \mathrm{Oct})$ of 2006 and 2007

\begin{tabular}{lllllll}
\hline Year & Season & $R_{\text {ref }}$ & $E_{0}$ & $R^{2}$ & $n$ & Model \\
\hline 2006 & Dormant & $2.44 \pm 0.02$ & $447 \pm 6.57$ & 0.67 & 3,706 & Eq. 1 \\
& Growing & $2.69 \pm 0.01$ & $a=40.49 \pm 0.54$ & 0.59 & 8,436 & Eq. 2 \\
& & $b=404.38 \pm 8.51$ & & & \\
2007 & Dormant & $2.29 \pm 0.03$ & $525 \pm 6.57$ & 0.61 & 4,523 & Eq. 1 \\
& Growing & $2.15 \pm 0.09$ & $299 \pm 3.65$ & 0.50 & 7,814 & Eq. 1 \\
\hline
\end{tabular}

In the 2006 growing season, soil moisture (SM) was included in the model using Eq. 2. All modeled parameters were highly significant $(P<0.001)$ 


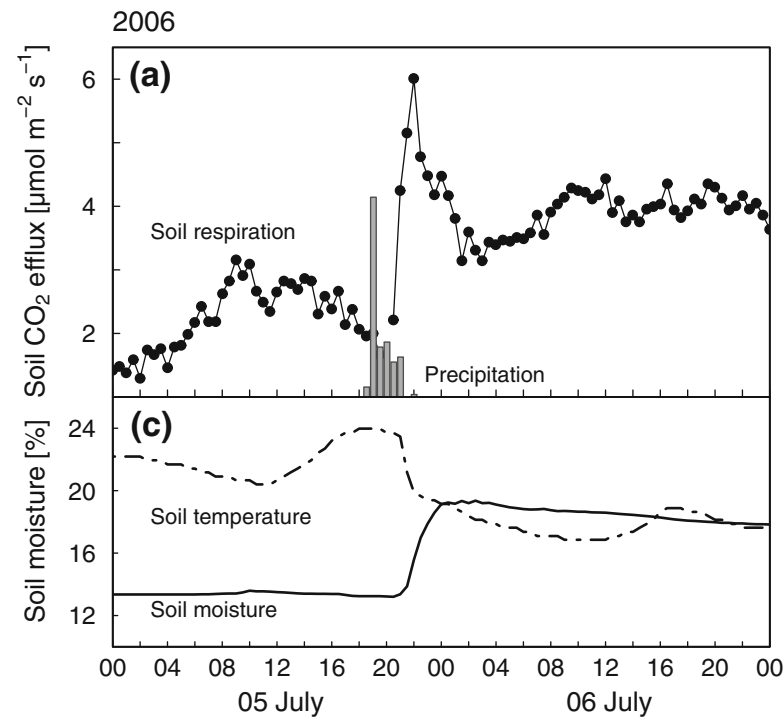

Fig. 5 Impact of heavy rain events on soil respiration. bf a, bf $\mathrm{b}$ : the time series of half-hourly $\mathrm{SR}_{\text {automated }}$ and the amount of precipitation for 2006 and 2007, respectively are shown. bf c,

rain event $(16 \mathrm{~mm})$ rewetted the soil and increased soil moisture to about $19 \%$ (Fig. 5a, c). Almost simultaneously, within $2 \mathrm{~h}$, this caused a pulse of $\mathrm{CO}_{2}$ from the soil, $\mathrm{SR}_{\text {automated }}$ increased by a factor of 3 from about 2 to $6 \mu \mathrm{mol} \mathrm{CO}_{2} \mathrm{~m}^{-2} \mathrm{~s}^{-1}$ (Fig. 5a). During the following $3 \mathrm{~h}, \mathrm{SR}_{\text {automated }}$ rates decreased again to about $4 \mu \mathrm{mol} \mathrm{CO}_{2} \mathrm{~m}^{-2} \mathrm{~s}^{-1}$, but remained significantly higher than prior to the rain event. In contrast, during the wet summer of 2007, when SR was not water limited, we found a very different response of $\mathrm{SR}_{\text {automated }}$ to very large rain events $(>10 \mathrm{~mm}$ in $30 \mathrm{~min})$. The first rain event increased soil moisture from 16 to $22 \%$, while the second rain event increased soil moisture only slightly from 21 to $24 \%$ (Fig. 5b, d). However, in both cases, $\mathrm{SR}_{\text {automated }}$ decreased by more than $50 \%$, from about 4 to about $1.5 \mu \mathrm{mol} \mathrm{CO} \mathrm{C}^{-2} \mathrm{~s}^{-1}$ almost instantaneously, probably caused by water logging of the soil pores. Despite such large responses of SR to individual rain events, we did not include them in the modelling of annual SR rates since such impacts of rain on $S_{\text {automated }}$ occurred only very sporadically at our study site.

Impact of temperature on SR in two contrasting winters

Not only rain events but also cold temperature and snow affect SR during the course of a year.

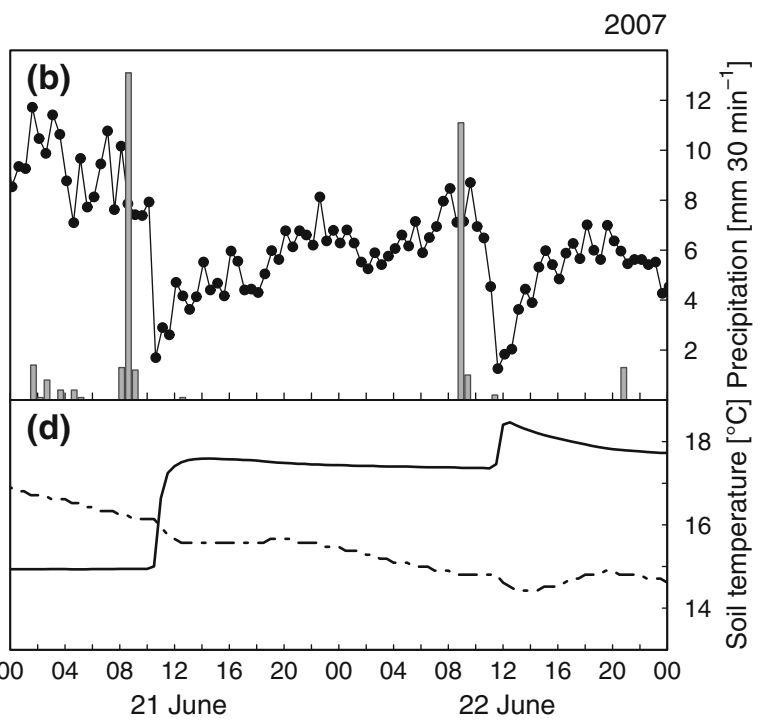

bf d: the time series of half-hourly soil moisture $(10 \mathrm{~cm}$ depth $)$ and soil temperature $(5 \mathrm{~cm} \mathrm{depth})$ are given

Comparing the coldest months at our site, i.e., January, February and March (JFM) of 2006 and 2007, offered the opportunity to examine two contrasting winter seasons. While the harsh winter in 2006 was characterized by a distinct snow cover and air temperatures mostly below zero degrees, the winter in 2007 was rather mild with hardly any snow cover and air temperatures mostly above zero degrees (mean air temperature $-1.03^{\circ} \mathrm{C}$ in 2006 vs. $3.96^{\circ} \mathrm{C}$ in 2007; mean soil temperature at $5 \mathrm{~cm}$ depth $1.35^{\circ} \mathrm{C}$ in 2006 vs. $5.04^{\circ} \mathrm{C}$ in 2007 ). On average, soil temperatures were about $4 \mathrm{~K}$ higher during winter 2007 than winter 2006 (Fig. 3e, f).

Since $\mathrm{SR}_{\text {manual }}$ measurements during JFM were not frequent enough, $\mathrm{SR}$ and soil temperature $(5 \mathrm{~cm})$ measured during the dormant season of each year was used to calculate the soil $\mathrm{CO}_{2}$ loss during these contrasting winter seasons using Eq. 1 (SR automated: see Table 1; $\mathrm{SR}_{\text {manual }}$ : 2006: $R^{2}=0.98, P<0.001$, $n=7, \quad R_{\text {ref }}=2.67, E_{0}=446 ; \quad 2007: \quad R^{2}=0.72$, $\left.P<0.05, n=5, R_{\text {ref }}=2.32, E_{0}=426\right)$. The resulting cumulative flux of $\mathrm{SR}_{\text {automated }}$ during JFM 2007 was with $80.8 \mathrm{~g} \mathrm{C} \mathrm{m}^{-2}$ (95\% confidence interval of [75.3, 86.4]) about 63\% higher than in 2006 with $49.6 \mathrm{~g} \mathrm{C} \mathrm{m}^{-2}$ (95\% confidence interval of [39.0, 61.6]). Thus, the winter months JFM contributed about $6 \%$ in 2006 , but $11 \%$ in 2007 to the annual $\mathrm{SR}_{\text {automated }}$ estimate (see Table 2). The same pattern 
was observed for the modeled cumulative flux of $\mathrm{SR}_{\text {manual }}$. The carbon loss in 2007 was with $106.5 \mathrm{~g} \mathrm{C}$ $\mathrm{m}^{-2}$ about $72 \%$ higher than in 2006 with $61.9 \mathrm{~g} \mathrm{C}$ $\mathrm{m}^{-2}$, while the amount of leaf litter fall during the previous autumn seasons was similar (2005: $307.5 \pm$ $28.4 \mathrm{~g} \mathrm{~m}^{-2}$, 2006: $284.3 \pm 19.1 \mathrm{~g} \mathrm{~m}^{-2}$ ). Thus, an increase in soil temperature of about $4 \mathrm{~K}$ in 2007 increased the cumulative $\mathrm{CO}_{2}$ loss from soils by about $60-70 \%$ compared to 2006. One could speculate that a soil temperature increase of about 5-6 K might double winter soil respiration at our study site if not limited by substrate supply.

\section{Annual soil respiration estimates}

Plot-wise modeling of $\mathrm{SR}_{\text {manual }}$ data resulted in annual SR estimates for the footprint area ranging from 638 to $1237 \mathrm{~g} \mathrm{C} \mathrm{m}^{-2}$ year $^{-1}$ in 2006 and from 701 to $1290 \mathrm{~g} \mathrm{C} \mathrm{m}^{-2}$ year $^{-1}$ in 2007 (Table 2). In general, plots with high annual SR rates in 2006 showed also high annual SR rates in 2007. Annual averages of $\mathrm{SR}_{\text {manual }}$ across all plots in the study site were not significantly different in 2006 (869 g C $\mathrm{m}^{-2}$ year $^{-1}$ ) compared to those in 2007 (907 $\mathrm{g} \mathrm{C}^{-}$ $\mathrm{m}^{-2}$ year $\left.^{-1}\right)$, as well as leaf litter input did not differ between the 2 years (Table 2). Variations among the 16 plots in SR were large, but could not be explained by differences in mean annual soil temperature, maximum LAI, leaf litterfall or fine root biomass (data not shown). Comparing the two different soil types present at our site using a $t$ test, we found no significant differences in annual SR rates, although leaf litter fall was significantly higher for the rendzina soils than for the cambisol soils (2006: $t=-4.64$, $P<0.001 ; 2007: t=-3.70, \quad P=0.002)$. The annual $\mathrm{SR}_{\text {automated }}$ estimate was $868 \mathrm{~g} \mathrm{C} \mathrm{m}^{-2}$ year $^{-1}$ for 2006 , well within the $95 \%$ confidence interval of the annual $\mathrm{SR}_{\text {manual }}$ estimate for our study site. However in 2007, the annual $\mathrm{SR}_{\text {automated }}$ estimate of $729 \mathrm{~g} \mathrm{C} \mathrm{m}^{-2}$ year $^{-1}$ was about $20 \%$ lower than the $\mathrm{SR}_{\text {manual }}$ estimate (Table 2).

Diurnal variations of soil respiration

Diurnal variations of SR calculated as differences between daily maximum and daily minimum values varied during the course of the years. In general, periods with greater diurnal variations in $\mathrm{SR}_{\text {automated }}$ rates coincided with high daily temperature variations. Monthly averaged diurnal variations of $\mathrm{SR}_{\text {automated }}$ for the two study years increased linearly with monthly averaged diurnal variations of air temperature $\left(R^{2}=0.78, P<0.001\right)$, but less so with soil temperature $\left(1 \mathrm{~cm}\right.$ depth: $R^{2}=0.43, P<0.01$; $5 \mathrm{~cm}$ depth: $\left.R^{2}=0.40, P<0.01\right)$.

To learn more about the relationships between diurnal variations of $\mathrm{SR}_{\text {automated }}$ rates and soil temperatures, we selected periods using the following criteria: (1) periods with more than 10 days of continuous soil respiration data, (2) pronounced diurnal variation of surface soil temperature $(1 \mathrm{~cm}$ depth) $>1.5 \mathrm{~K}$, and (3) no major rain event $(<5 \mathrm{~mm}$ in $30 \mathrm{~min}$ ). Only four periods met these strict criteria: 07-27 July 2006 (July), 14-27 August 2006 (Aug), 01-25 September 2006 (Sep) and 15 April to 3 Mai 2007 (April). During these periods, the diurnal variations of surface soil temperature were quite pronounced $(1.8-3.3 \mathrm{~K})$, decreasing with soil depth to about $0.6 \mathrm{~K}$ at $10 \mathrm{~cm}$. At the same time, diurnal variations of SR were about $0.4-0.8 \mu \mathrm{mol} \quad \mathrm{CO}_{2}$ $\mathrm{m}^{-2} \mathrm{~s}^{-1}$, with lowest $\mathrm{SR}$ rates between 9-12 h and highest SR rates between 17-19 h, following the course of soil temperature with some delay (Fig. 6b-h). However, this was not the case during the July 2006 period, when SR was water limited (Fig. 6a, e). During this period, SR increased during the night, while soil temperatures still decreased. Therefore, a counterclockwise hysteresis of SR was found after plotting $\mathrm{SR}_{\text {automated }}$ against soil temperature for Aug, Sep and April (Fig. 7a), i.e., the soil respiration rates lagged soil temperature $(1 \mathrm{~cm}$ depth) by several hours and were generally higher during the night compared to the day at the same soil temperature (Fig. 7a, grey dot represents SR at 1:00 h). To further test the hypothesis of a time-lag in SR to soil temperature, we investigated the relationships of $\mathrm{SR}_{\text {automated }}$ shifted forward between 0 and $12 \mathrm{~h}$ with soil temperature at different depths using Eq. 1, and compared the models with Akaike's Information Criterion (Table 3). While the relationship between non-lagged SR ( $0 \mathrm{~h}$ forward shift) and soil temperature in $1 \mathrm{~cm}$ depth was weak $\left(R^{2}\right.$ between 0.04 and $0.36)$, the strength of the relationship increased with depth where soil temperature was measured $\left(R^{2}\right.$ between 0.48 and 0.83 ). However, also the temperature sensitivities increased, resulting in unrealistic high temperature sensitivities of SR with $E_{0}>1,000 \mathrm{~K}^{-1}$ for soil temperatures at $10 \mathrm{~cm}$ depth (data not 


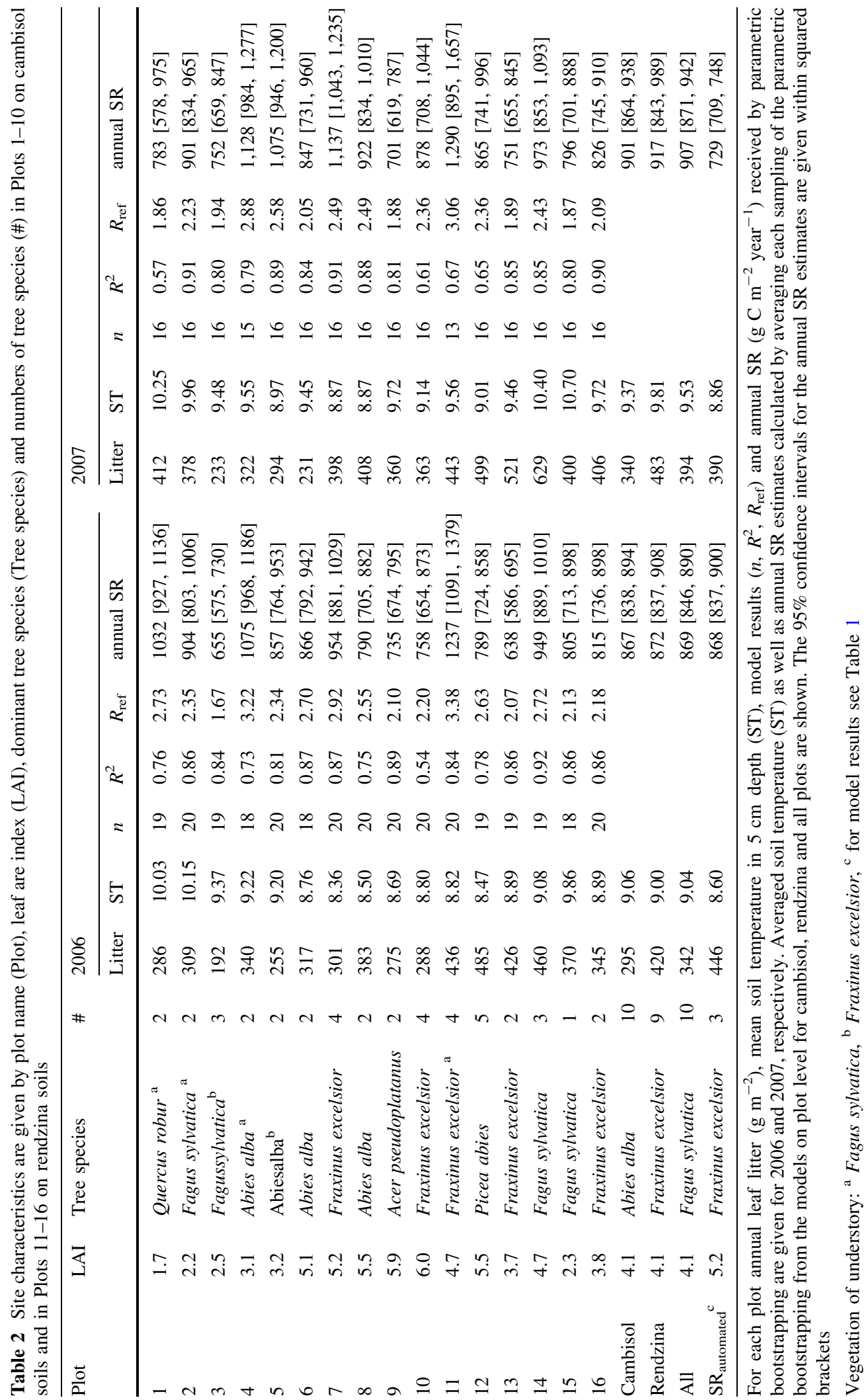




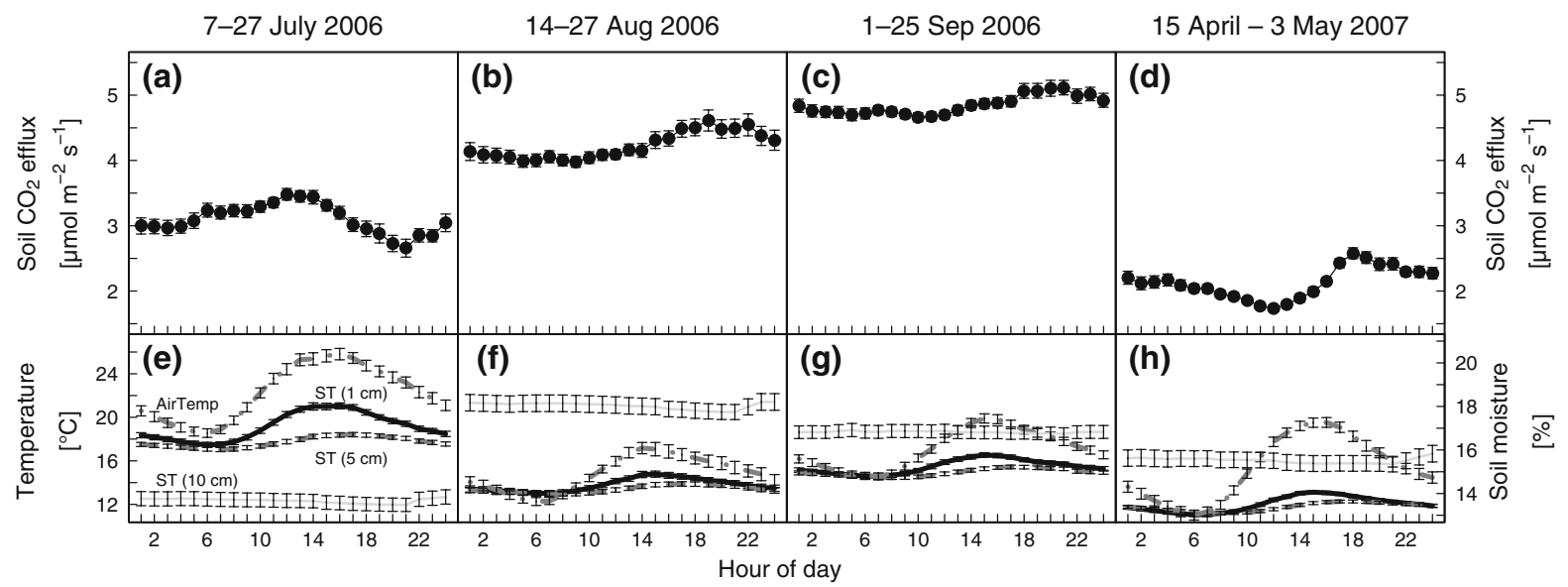

Fig. 6 Diurnal variations of soil respiration for selected periods. Shown are hourly rates of $\mathrm{SR}_{\text {automated }}$ averaged over the respective period in 2006 and 2007 (a-d). Hourly air

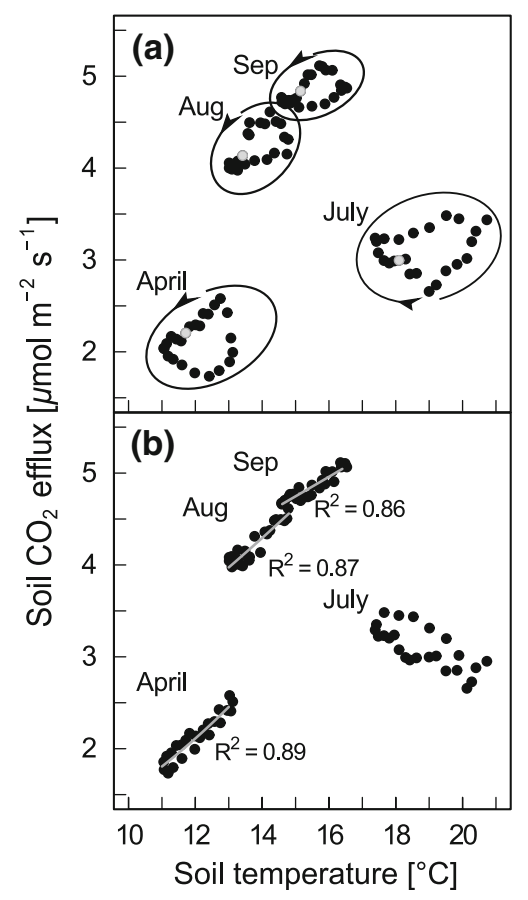

Fig. 7 Diurnal variations and time-lag of soil respiration versus soil temperature for selected periods. Hourly $\mathrm{SR}_{\text {automated }}$ rates averaged over the periods 7-27 July 2006 (July), 14-27 August 2006 (Aug), 1-25 September 2006 (Sep) and 15 April to 03 May 2007 (April) are plotted against soil temperature (1 $\mathrm{cm}$ depth). In a SR at 1:00 $\mathrm{h}$ is represented by the grey dots and the direction of the hysteresis is indicated by the arrows. In b $\mathrm{SR}_{\text {automated }}$ is plotted with a time lag of $4 \mathrm{~h}$ versus soil temperature (SR lagging soil temperature) and the $R^{2}$ of the relationship, as well as the best fit are given by the solid grey lines (Eq. 1) temperature (AirTemp), soil temperature (ST) in 1 and $5 \mathrm{~cm}$ depth as well as soil moisture in $10 \mathrm{~cm}$ depth are also given (e-h). Bars are $\pm 1 \mathrm{SE}$

shown). Comparing all regression models, the best fit (smallest AIC) of SR to soil temperature was found for SR with a 2-4 h lag compared to soil temperature at 1 and $5 \mathrm{~cm}$ depth. With a $4 \mathrm{~h}$ time lag, the hysteresis of SR with soil temperature disappeared (Fig. 7b). For the drought period in July 2006, we found a clockwise hysteresis, i.e., the diurnal course of SR was lagged by soil temperature (Fig. 7a, b). To investigate the consequences of these findings over longer time scales, we analysed $\mathrm{SR}_{\text {automated }}$ data (dormant and growing season) assuming time lags of SR of 1-4 h. However, the thereby resulting models did not improve in comparison to the models from Table 1. Thus, the time lag of SR to soil temperature was not consistent at shorter and longer time periods but occurred only when diurnal variations of surface soil temperatures were pronounced.

\section{Discussion}

Seasonal course of soil respiration

Highly different seasonal and diurnal courses of SR were observed during 2006 and 2007 in a mixed mountain forest on a South-facing slope in the Swiss Jura. Soil respiration could be modeled using soil temperature as single predictive variable with a high coefficient of determination, if soil water was not limiting (Fig. 4). Including soil moisture into the 
Table 3 Coefficients of determination for non-lagged and lagged diurnal variations of soil respiration with soil temperature in 1, 5 or $10 \mathrm{~cm}$ depth (ST) for the three periods: 14-27 August 2006 (Aug 06), 01-25 September 2006 (Sep 06), and 15 April to 03 May 2007 (April 07)

\begin{tabular}{|c|c|c|c|c|c|c|}
\hline & $R^{2}$ for non- & soil respirati & & $R^{2}$ for lagg & respiration & \\
\hline & $\mathrm{ST}(1 \mathrm{~cm})$ & $\mathrm{ST}(5 \mathrm{~cm})$ & $\mathrm{ST}(10 \mathrm{~cm})$ & $\mathrm{ST}(1 \mathrm{~cm})$ & $\mathrm{ST}(5 \mathrm{~cm})$ & $\mathrm{ST}(10 \mathrm{~cm})$ \\
\hline Aug 06 & 0.36 & 0.71 & 0.83 & $0.90^{(3) \mathrm{a}}$ & $0.89^{(2)}$ & $0.74^{(1)}$ \\
\hline Sep 06 & 0.23 & 0.65 & 0.83 & $0.86^{(4)}$ & $0.87^{(2) a}$ & $0.85^{(1)}$ \\
\hline April 07 & $0.04^{\text {n.s. }}$ & 0.48 & 0.73 & $0.89^{(4) a}$ & $0.87^{(2)}$ & $0.83^{(1)}$ \\
\hline
\end{tabular}

Only the $R^{2}$ of the best fit (smallest AIC) of time lagged $\mathrm{SR}_{\text {automated }}$ is given for each soil temperature; numbers in parenthesis indicate the hours of the time lag (all regressions were significant $(P \leq 0.05)$ if not otherwise stated)

${ }^{a}$ Best fit over all temperatures

model (Eq. 2) allowed us to predict SR rates also very accurately during the 2006 summer drought. However, not all temporal variations in SR could be explained by soil temperature and soil moisture, indicating that temporal variations of SR were coupled to further environmental drivers such as substrate availability, photosynthesis and precipitation (Kirschbaum 2004; Tang et al. 2005a; Buchmann et al. 1997).

Impact of rain events on soil respiration

It is commonly observed in many ecosystems that SR can be enhanced after rain (e.g, Birch 1958; Lee et al. 2004; Jarvis et al. 2007) although other authors report SR being suppressed when soil pores become water logged (e.g, Buchmann et al. 1997; Bowden et al. 1998; Hirano et al. 2003). However, to our knowledge, this is the first study in which both contrasting effects of rain on SR were observed within one ecosystem. Rapid rewetting after soil drying often yields a pulse of $\mathrm{CO}_{2}$ from the soils (Birch 1958; Xu et al. 2004; Jarvis et al. 2007). Different reasons could come into play: (1) The replacement of $\mathrm{CO}_{2}$ rich soil air by rain water could explain this pattern. However, assuming a $\mathrm{CO}_{2}$ concentration of $2000 \mathrm{ppm}$ in soil air and $\mathrm{CO}_{2}$ evolving from the upper $20 \mathrm{~cm}$ of the soil, the replacement of $6 \%$ of soil air would have created a pulse of $0.6 \mu \mathrm{mol}$ $\mathrm{CO}_{2} \mathrm{~m}^{-2} \mathrm{~s}^{-1}$ during $30 \mathrm{~min}$, directly after soil rewetting. (2) Most probably, soil microbes are responsible for producing this pulse, due to mineralization of destabilized soil organic matter during drying and rewetting cycles, or due to additional mineralization of microbial $\mathrm{C}$, which becomes available after microbial cell lyse and/or by the release of osmoregulatory solutes (e.g., Fierer and Schimel 2003; Jarvis et al. 2007). Such pulses of $\mathrm{CO}_{2}$ can significantly alter the net annual carbon gain of Mediterranean ecosystems (Jarvis et al. 2007). However, this is very unlikely for our study site as these pulses were very scarce.

On the other hand, SR can also be suppressed by moderate to high soil moisture, because $\mathrm{CO}_{2}$ diffusion out of the soil and $\mathrm{O}_{2}$ diffusion into the soil are limited, decreasing aerobic autotrophic and heterotrophic respiration. In a soil incubation experiment, Bowden et al. (1998) found that SR increased with increasing soil moisture, but declined at water holding capacity $>80 \%$. In our study, we observed a fast decrease of $\mathrm{SR}_{\text {automated }}$ of about $50 \%$ after a strong rain event $(>10 \mathrm{~mm}$ in $30 \mathrm{~min})$ at moderate soil moisture conditions (16\%). The same response was observed in an Amazonian rainforest, where SR rates were found to decrease by about $40 \%$ after heavy rain (Buchmann et al. 1997). Similar findings are also reported from a deciduous forest in Japan, where SR was measured continuously using a $\mathrm{CO}_{2}$ concentration profile (Hirano et al. 2003). After rain, diffusion was low, $\mathrm{CO}_{2}$ concentration increased in the soil pore space and SR decreased by about $15 \%$ during and directly after the rain event. This comparatively small reduction could be due to the less intense rain event $\left(<5 \mathrm{~mm} \mathrm{~h}^{-1}\right)$ and the low respiration rates before rain. In general, the direct effects of summer rain on SR observed in our study might be of concern for those measuring SR manually to generate models, since measurements made after such rain events could significantly bias modelled seasonal or annual soil respiration. 
Winter soil respiration

During winter, when tree activity is strongly reduced, SR is typically dominated by heterotrophic respiration (Tang et al. 2005b; Schindlbacher et al. 2007; Ruehr and Buchmann submitted), thus increasing winter temperatures mainly enhances decomposition of litter and soil organic matter. Winter air temperatures (January-March) at our study site were about $5 \mathrm{~K}$ higher during the mild winter in 2007 compared to the harsh winter in 2006, while soil temperature $(5 \mathrm{~cm}$ depth) increased only by $4 \mathrm{~K}$, probably due to snow cover and its thermal insulation of the soil. Nevertheless, carbon dioxide loss increased by about 60-70\% from winter 2006 to winter 2007, most likely due to enhanced microbial decomposition caused by higher temperatures since substrate availability estimated from leaf litter fall and its species composition (data not shown) of the two previous autumn seasons (2005 and 2006) were very similar. The SR rates measured during both winter seasons at soil temperatures below $5^{\circ} \mathrm{C}$ were in good accordance to other studies in forest ecosystems (e.g., Hirano 2005; Schindlbacher et al. 2007).

Since temperate ecosystems act as a carbon source to the atmosphere during winter periods (e.g., Malhi et al. 1999), monitoring winter carbon loss will become more important in a warmer world. In subalpine forests, the amount of carbon lost during winter can be as much as $50-90 \%$ of the carbon gained in the previous summer (Monson et al. 2005). For our study site, the longterm (1987-2007) mean air temperature during January to March is about $1.5^{\circ} \mathrm{C}$. In the future, a mild winter like the one in 2007 might become more regular, as a temperature increase of about $0.9-3.4 \mathrm{~K}$ is predicted for this region until 2050 (OcCC 2007). However, the effects of increasing temperatures on litter and soil organic matter decomposition and their potential feedback on climate change are still a matter of debate (Davidson and Janssens 2006). On the one hand, soil respiration is thought to be more sensitive to temperature than primary production, and thus climate warming should increase the net loss of carbon from soils to the atmosphere (Jenkinson et al. 1991). On the other hand, decomposition rates could also become limited due to depletion of readily decomposable substrate
(Kirschbaum 2004). However during winter, a large amount of easily decomposable organic matter is typically available to soil microbes after leaf litter fall in temperate deciduous and mixed forests, therefore decomposition should not be limited by substrate availability but rather by temperature in these forests. Thus, enhanced carbon loss from soils of mixed and deciduous mountain forests is very likely in future winters.

Annual soil respiration estimates

Despite pronounced differences in temperature and precipitation during winter and summer seasons of the two study years, mean annual temperatures and amounts of precipitation as well as annual $\mathrm{SR}_{\text {manual }}$ rates were comparable between the two study years. While we found annual $\mathrm{SR}_{\text {automated }}$ rates in 2007 to be about $15 \%$ lower compared to 2006 (and 20\% lower than annual $\mathrm{SR}_{\text {manual }}$ rates in 2007). This decrease in $\mathrm{SR}_{\text {automated }}$ rates could have probably resulted from a "chamber installation effect", since we did not change the location of the collar and the chamber since June 2006. The Li-8100-101 chamber is mounted on a frame to hold free from the soil surface. But this frame is still covering the soil surrounding the collar by about $5 \mathrm{~cm}$ wide just like a tiny roof. When the chamber is open (c. $90 \%$ of the time) another about $350 \mathrm{~cm}^{2}$ of the adjacent soil is covered. This might have reduced precipitation and litter input to the soil, and thereby contributed to the lower estimates of $\mathrm{SR}_{\text {automated }}$ in 2007.

Nevertheless, the Lägeren forest lost on average about $900 \mathrm{~g} \mathrm{C} \mathrm{m}^{-2}$ year $^{-1}$ via soil respiration during the two study years (Table 2; with an uncertainty $<10 \%$ at the $95 \%$ confidence interval), well within the range of estimates of other beech-dominated forests in Europe (Table 4), except the youngest (Hesse) and the most Northern forest (Lille Boegeskov), which had much lower annual SR rates. Compared to a spruce dominated forest (Weidenbrunnen), comparable in altitude and stand age to our study site, the beech forests showed much higher annual SR rates, due to vegetation type, higher mean annual temperature and/ or to differences in SR measurement techniques (Table 4). These findings indicate that similar processes underlay SR in beech-dominated forests on mountain slopes as on flat terrain. 
Table 4 Annual estimates of soil respiration for beech and mountain forests in Europe

\begin{tabular}{|c|c|c|c|c|c|c|c|c|}
\hline Site & $\begin{array}{l}\text { Elevation } \\
\text { (m a.s.1.) }\end{array}$ & $\begin{array}{l}\text { Slope } \\
(\%)\end{array}$ & $\begin{array}{l}\text { Age } \\
\text { (years) }\end{array}$ & $\begin{array}{l}\text { Temp } \\
\left({ }^{\circ} \mathrm{C}\right)\end{array}$ & $\begin{array}{l}\text { Precip } \\
(\mathrm{mm})\end{array}$ & Period & SR & References \\
\hline Lägeren $(\mathrm{CH})^{\mathrm{a}, \mathrm{c}}$ & 700 & 45 & $50-150$ & 8.4 & 930 & $\begin{array}{l}2006 \\
2007\end{array}$ & $\begin{array}{l}869 \\
907\end{array}$ & This study \\
\hline Collelongo $(\mathrm{I})^{\mathrm{a}, \mathrm{c}}$ & 1,550 & - & 90 & 7.4 & 1,100 & 1996-1997 & 879 & Matteucci et al. (2000) \\
\hline Vielsalm $(\mathrm{BE})^{\mathrm{a}, \mathrm{c}}$ & 450 & 3 & $60-90$ & 7.5 & 1,000 & 1997-1998 & 870 & Longdoz et al. (2000) \\
\hline Hainich (D) $)^{\mathrm{a}, \mathrm{c}}$ & 445 & $3-5$ & $0-250$ & 7.8 & 800 & $\begin{array}{l}2000 \\
2001 \\
2002\end{array}$ & $\begin{array}{l}908 \\
919 \\
896\end{array}$ & Knohl et al. (2008) \\
\hline Hesse $(F)^{a, c}$ & 300 & $0-5$ & 30 & 9.2 & 820 & $\begin{array}{l}1996 \\
1997\end{array}$ & $\begin{array}{l}575 \\
663\end{array}$ & Epron et al. (1999) \\
\hline Lille Boegeskov $(\mathrm{DK})^{\mathrm{a}, \mathrm{d}}$ & 40 & 0 & 80 & 8.1 & 600 & $\begin{array}{l}1996 \\
1997\end{array}$ & $\begin{array}{l}368 \\
457\end{array}$ & Pilegaard et al. (2001) \\
\hline Weidenbrunnen $2(\mathrm{D})^{\mathrm{b}, \mathrm{e}}$ & 760 & 2 & 112 & 6.0 & 1,019 & $\begin{array}{l}1997 \\
1998 \\
1999 \\
2000\end{array}$ & $\begin{array}{l}497 \\
566 \\
592 \\
586\end{array}$ & Subke et al. (2003) \\
\hline
\end{tabular}

Elevation, average slope, mean stand age, air temperature (Temp) and precipitation (Precip) as well as annual soil respiration estimates $\left(\mathrm{g} \mathrm{C} \mathrm{m}^{-2}\right.$ year $\left.^{-1}\right)$ are given

-, no prevalent slope, variable topography

a Overstory dominated by Fagus sylvatica

b Overstory dominated by Picea abies

c Closed chamber (manual)

d Closed chamber (campaign-wise automatic)

e Open chamber (semi-automatic)

Time lags of SR vs. soil temperature

During periods when SR was not water-limited, a pronounced counterclockwise hysteresis between SR and surface soil temperature was observed, similar to a study from Gaumont-Guay et al. (2006) for a boreal aspen forest. In their study, soil respiration peaked $3.5-5 \mathrm{~h}$ later than soil temperature at $2 \mathrm{~cm}$ depth while soil moisture did not change over the day. However, they did not find SR to lag soil temperature at $10 \mathrm{~cm}$ depth, but similar to our study — an unusually high temperature sensitivity-of this relationship $\left(Q_{10}>150\right)$ was reported. Such an unrealistic temperature sensitivity of SR arises because $\mathrm{CO}_{2}$ production from the upper soil layers is compared to a relatively small temperature change in $10 \mathrm{~cm}$ depth. Therefore, we argue that surface soil temperature (1-5 cm depth) is most suitable to model diurnal variations in $\mathrm{SR}_{\text {automated }}$ with a time-lag of $2-4 \mathrm{~h}$ (if respiration is not limited by water availability).
The reason for the observed lag of SR to soil temperature could either be (1) a physically driven process from the production of $\mathrm{CO}_{2}$ to its diffusion from the soil surface (e.g., Jassal et al. 2004), (2) a biologically driven process caused by direct supply of the root-rhizosphere with recently assimilated carbon as some studies indicate (e.g., Tang et al. 2005a) or (3) a combination of physical and biological processes (Riveros-Iregui et al. 2007). At our study site, photosynthesis reached its maximum at around midday (S. Etzold 2008, personal communication), 6-8 h earlier than $\mathrm{SR}_{\text {automated. }}$ A similar pattern was found in an oak-grass savanna where the peak in SR lagged photosynthesis by about 7-12 h (Tang et al. 2005a). Tang et al. (2005a) concluded that the short time lag may not be due to the real transport of carbohydrates in the phloem translocation stream, but due to the propagation of pressure and concentration fronts, which arrive much faster in the sink organs than in the solution itself (Thompson and Holbrook 2004). 
For a montane conifer forest, Riveros-Iregui et al. (2007) found the degree of hysteresis between soil $\mathrm{CO}_{2}$ production and soil temperature to decrease with declining water content during the growing season. In contrast, we found still a strong hysteresis effect under water-limited conditions, although in the opposite, clockwise direction (i.e., SR increased before soil temperature) during the drought spell in July 2006. Then, $\mathrm{SR}_{\text {automated }}$ increased during the night (when soil temperature decreased) and peaked at midday. The reasons are less clear: Trees mostly refill their stem water reserves during night, when transpiration is low. Water uptake during night can also lead to hydraulic redistribution of soil water from deeper and moister soil layers to the more shallower drier soil via the root system (Caldwell et al. 1998) and could therefore increase both rootrhizosphere and microbial respiration (see Carbone et al. 2008). Using dendrometers at an ash tree next to the $\mathrm{SR}_{\text {automated }}$ measurements (within $2 \mathrm{~m}$ ), we observed a distinct diurnal variation of the trunk diameter during the drought period in July 2006. Tree trunk diameter increased during the night until the next morning, caused mainly by water uptake and storage, followed by a decrease in the late morning due to enhanced transpiration (Ruehr, unpublished data). However, no significant change of soil moisture was seen during the diurnal cycle (Fig. 6), suggesting that only the water content of roots and their adjacent rhizosphere was enhanced which could not be detected in the bulk soil where soil moisture was measured. Thus, increasing nighttime SR during the 2006 summer drought might be the result of water redistribution from deeper soil layers to shallower fine roots, which would cause root-rhizosphere respiration to increase. However, to provide further evidence detailed research on soilplant water interactions is needed.

Acknowledgments We would like to thank our colleagues for their great support: Werner Eugster, Peter Plüss, Sophia Etzold, Matthias Zeeman, Veronika Elgart, Linda Wehrli, Anni Düsteler and Joshua Bizozzero. Precipitation and air temperature data were made avialable to us through Christoph Hüglin (EMPA). We thank Philipp Vock and his team from the forest district Wettingen for their kind cooperation. This project was part of the COST Action E38 and funded by the Staatssekretariat für Bildung und Forschung (SBF, project number C04.0255), Bern, Switzerland.

\section{References}

Birch H (1958) The effect of soil drying on humus decomposition and nitrogen availability. Plant Soil 10(1):9-31

Bowden R, Newkirk K, Rullo G (1998) Carbon dioxide and methane fluxes by a forest soil under laboratory-controlled moisture and temperature conditions. Soil Biol Biochem 30:1591-1597

Brassel P, Brändli UB (eds) (1999) Schweizerisches Landesforstinventar: Ergebnisse der Zweitaufnahme 19931995. Eidgenössische Forschungsanstalt für Wald, Schnee und Landschaft, WSL, Birmensdorf; Bundesamt für Umwelt, Wald und Landschaft, BUWAL Bern. Haupt, Bern, Bern, Stuttgart, Wien

Buchmann N, Guehl J, Barigah T, Ehleringer J (1997) Interseasonal comparison of $\mathrm{CO}_{2}$ concentrations, isotopic composition, and carbon dynamics in an Amazonian rainforest (French Guiana). Oecologia 110(1):120-131

Burton AJ, Melillo JM, Frey SD (2008) Adjustment of forest ecosystem root respiration as temperature warms. J Integr Plant Biol 50(11):1467-1483

Caldwell MM, Dawson TE, Richards JH (1998) Hydraulic lift: consequences of water efflux from the roots of plants. Oecologia 113(2):151-161

Carbone MS, Winston GC, Trumbore SE (2008) Soil respiration in perennial grass and shrub ecosystems: linking environmental controls with plant and microbial sources on seasonal and diel timescales. J Geophys Res Biogeosci 113(G2). doi:10.1029/2007JG000611

Davidson EA, Janssens IA (2006) Temperature sensitivity of soil carbon decomposition and feedbacks to climate change. Nature 440(7081):165-173

Davidson EA, Trumbore SE, Amundson R (2000) Biogeochemistry-soil warming and organic carbon content. Nature 408(6814):789-790

Davidson E, Savage K, Verchot L, Navarro R (2002) Minimizing artifacts and biases in chamber-based measurements of soil respiration. Agric For Meteorol 113: 21-37

Epron D, Farque L, Lucot E, Badot P (1999) Soil $\mathrm{CO}_{2}$ efflux in a beech forest: dependence on soil temperature and soil water content. Ann For Sci 56:221-226

Fierer N, Schimel J (2003) A proposed mechanism for the pulse in carbon dioxide production commonly observed following the rapid rewetting of a dry soil. Soil Sci Soc Am J 67:798-805

Gaumont-Guay D, Black TA, Griffis TJ, Barr AG, Jassal RS, Nesic Z (2006) Interpreting the dependence of soil respiration on soil temperature and water content in a boreal aspen stand. Agric For Meteorol 140:220-235

Giardina CP, Ryan MG (2000) Evidence that decomposition rates of organic carbon in mineral soil do not vary with temperature. Nature 404(6780):858-861

Hanson PJ, Wullschleger SD, Bohlman SA, Todd DE (1993) Seasonal and topographic patterns of forest floor $\mathrm{CO}_{2}$ efflux from an upland oak forest. Tree Physiol 13(1):1-15

Heim A, Wehrli L, Eugster W, Schmidt MWI (2009) Effects of sampling design on the probability to detect soil carbon 
stock changes at the Swiss Carbo Europe site Lägeren. Geoderma 149(3-4):347-354

Heimann M, Reichstein M (2008) Terrestrial ecosystem carbon dynamics and climate feedbacks. Nature 451(7176): 289-292

Hirano T (2005) Seasonal and diurnal variations in topsoil and subsoil respiration under snowpack in a temperate deciduous forest. Glob Biogeochem Cycles 19(GB2011). doi:10.1029/2004GB002259

Hirano T, Kim H, Tanaka Y (2003) Long-term half-hourly measurement of soil $\mathrm{CO}_{2}$ concentration and soil respiration in a temperate deciduous forest. J Geophys Res Atmos 108(D20). doi:10.1029/2003JD003766

IPCC (2007) Climate change 2007: the physical science basis. Contribution of working group I to the fourth assessment report of the intergovernmental panel on climate change. Cambridge University Press, Cambridge UK; NY USA

IUSS Working Group WRB (2007) World reference base for soil resources 2006. World Soil Resources Reports No. 103. FAO, Rome

Janssens I, Pilegaard K (2003) Large seasonal changes in $Q_{10}$ of soil respiration in a beech forest. Glob Change Biol 9:911-918

Janssens IA, Lankreijer H, Matteucci G, Kowalski AS, Buchmann N, Epron D, Pilegaard K, Kutsch W, Longdoz B, Grunwald T, Montagnani L, Dore S, Rebmann C, Moors EJ, Grelle A, Rannik U, Morgenstern K, Oltchev S, Clement R, Gudmundsson J, Minerbi S, Berbigier P, Ibrom A, Moncrieff J, Aubinet M, Bernhofer C, Jensen NO, Vesala T, Granier A, Schulze ED, Lindroth A, Dolman AJ, Jarvis PG, Ceulemans R, Valentini R (2001) Productivity overshadows temperature in determining soil and ecosystem respiration across European forests. Glob Change Biol 7(3):269-278

Jarvis P, Rey A, Petsikos C, Wingate L, Rayment M, Pereira J, Banza J, David J, Miglietta F, Borghetti M, Manca G, Valentini R (2007) Drying and wetting of Mediterranean soils stimulates decomposition and carbon dioxide emission: the "Birch effect". Tree Physiol 27:929-940

Jassal RS, Black TA, Drewitt GB, Novak MD, Gaumont-Guay D, Nesic Z (2004) A model of the production and transport of $\mathrm{CO}_{2}$ in soil: predicting soil $\mathrm{CO}_{2}$ concentrations and $\mathrm{CO}_{2}$ efflux from a forest floor. Agric For Meteorol 124(3-4): 219-236

Jenkinson D, Adams D, Wild A (1991) Model estimates of $\mathrm{CO}_{2}$ emissions from soil in response to global warming. Nature 351(6324):304-306

Kang S, Doh S, Lee D, Lee D, Jin V, Kimball J (2003) Topographic and climatic controls on soil respiration in six temperate mixed-hardwood forest slopes, Korea. Glob Change Biol 9:1427-1437

Kirschbaum M (2004) Soil respiration under prolonged soil warming: are rate reductions caused by acclimation or substrate loss? Glob Change Biol 10(11):1870-1877

Knohl A, Soe ARB, Kutsch WL, Goeckede M, Buchmann N (2008) Representative estimates of soil and ecosystem respiration in an old beech forest. Plant Soil 302:189-202

Knorr W, Prentice IC, House JI, Holland EA (2005) Long-term sensitivity of soil carbon turnover to warming. Nature 433(7023):298-301
Kvalseth TO (1985) Cautionary note about $\mathrm{R}^{2}$. Am Stat 39(4):279-285

Lee X, Wu H, Sigler J, Oishi C, Siccama T (2004) Rapid and transient response of soil respiration to rain. Glob Change Biol 10:1017-1026

Liski J, Ilvesniemi $\mathrm{H}$, Makela A, Westman C (1999) $\mathrm{CO}_{2}$ emissions from soil in response to climatic warming are overestimated-the decomposition of old soil organic matter is tolerant of temperature. Ambio 28(2): 171-174

Lloyd J, Taylor JA (1994) On the temperature-dependence of soil respiration. Funct Ecol 8(3):315-323

Longdoz B, Yernaux M, Aubinet M (2000) Soil $\mathrm{CO}_{2}$ efflux measurements in a mixed forest: impact of chamber disturbances, spatial variability and seasonal evolution. Glob Change Biol 6:907-917

Malhi Y, Baldocchi D, Jarvis P (1999) The carbon balance of tropical, temperate and boreal forests. Plant Cell Environ 22:715-740

Mariko S, Nishimura N, Mo W, Matsui Y, Kibe T, Koizumi H (2000) Winter $\mathrm{CO}_{2}$ flux from soil and snow surfaces in a cool-temperate deciduous forest, Japan. Ecol Res 15(4): 363-372

Mast M, Wickland K, Striegl R, Clow D (1998) Winter fluxes of $\mathrm{CO}_{2}$ and $\mathrm{CH}_{4}$ from subalpine soils in Rocky Mountain National Park, Colorado. Glob Biogeochem Cycles 12(4):607-620

Matteucci G, Dore S, Stivanello S, Rebmann C, Buchmann N (2000) Soil respiration in beech and spruce forests in Europe: trends, controlling factors, annual budgets and implications for the ecosystem carbon balance. In: Schulze ED (ed) Carbon and nitrogen cycling in European forests ecosystems, Ecological Studies, vol 142. Springer Verlag, Berlin-Heidelberg, pp 217-236

McDowell N, Marshall J, Hooker T, Musselman R (2000) Estimating $\mathrm{CO}_{2}$ flux from snowpacks at three sites in the Rocky Mountains. Tree Physiol 20(11):745-753

Monson R, Sparks J, Rosenstiel T, Scott-Denton L, Huxman T, Harley P, Turnipseed A, Burns S, Backlund B, Hu J (2005) Climatic influences on net ecosystem $\mathrm{CO}_{2}$ exchange during the transition from wintertime carbon source to springtime carbon sink in a high-elevation, subalpine forest. Oecologia 146:130-147

Monson RK, Burns SP, Williams MW, Delany AC, Weintraub M, Lipson DA (2006) The contribution of beneath-snow soil respiration to total ecosystem respiration in a highelevation, subalpine forest. Glob Biogeochem Cycles 20(3). doi:10.1029/2005GB002684

OcCC (2007) Klimaänderung und die Schweiz 2050. Erwartete Auswirkungen auf Umwelt, Gesellschaft und Wirtschaft. OcCC/ProClim, Bern

Pilegaard K, Hummelshoj P, Jensen N, Chen Z (2001) Two years of continuous $\mathrm{CO}_{2}$ eddy-flux measurements over a Danish beech forest. Agric For Meteorol 107:29-41

R Development Core Team (2007) R: a language and environment for statistical computing. R Foundation for Statistical Computing, Vienna, Austria

Reichstein M, Rey A, Freibauer A, Tenhunen J, Valentini R, Banza J, Casals P, Cheng YF, Grunzweig JM, Irvine J, 
Joffre R, Law BE, Loustau D, Miglietta F, Oechel W, Ourcival JM, Pereira JS, Peressotti A, Ponti F, Qi Y, Rambal S, Rayment M, Romanya J, Rossi F, Tedeschi V, Tirone G, Xu M, Yakir D (2003) Modeling temporal and large-scale spatial variability of soil respiration from soil water availability, temperature and vegetation productivity indices. Glob Biogeochem Cycles 17(4):1-15

Riveros-Iregui DA, Emanuel RE, Muth DJ, McGlynn BL, Epstein HE, Welsch DL, Pacific VJ, Wraith JM (2007) Diurnal hysteresis between soil $\mathrm{CO}_{2}$ and soil temperature is controlled by soil water content. Geophys Res Lett 34 . doi:10.1029/2007GL030938

Savage K, Davidson E (2003) A comparison of manual and automated systems for soil $\mathrm{CO}_{2}$ flux measurements: tradeoffs between spatial and temporal resolution. J Exp Bot 54:891-899

Schindlbacher A, Zechmeister-Boltenstern S, Glatzel G, Jandl $R$ (2007) Winter soil respiration from an Austrian mountain forest. Agric For Meteorol 146:205-215

Schlesinger WH, Andrews JA (2000) Soil respiration and the global carbon cycle. Biogeochemistry 48(1):7-20

Subke J, Reichstein M, Tenhunen J (2003) Explaining temporal variation in soil $\mathrm{CO}_{2}$ efflux in a mature spruce forest in Southern Germany. Soil Biol Biochem 35(11):1467-1483

Tang J, Baldocchi D, Xu L (2005a) Tree photosynthesis modulates soil respiration on a diurnal time scale. Glob Change Biol 11:1298-1304

Tang J, Misson L, Gershenson A, Cheng W, Goldstein A (2005b) Continuous measurements of soil respiration with and without roots in a ponderosa pine plantation in the Sierra Nevada Mountains. Agric For Meteorol 132: 212-227

Thompson M, Holbrook N (2004) Scaling phloem transport: information transmission. Plant Cell Environ 27(4): 509-519

UNEP-WCMC (2000) United Nations Environment Programme, World Conservation Monitoring Center. Mountains and mountain forests

Valentini R, Matteucci G, Dolman A, Schulze E, Rebmann C, Moors E, Granier A, Gross P, Jensen N, Pilegaard K, Lindroth A, Grelle A, Bernhofer C, Grunwald T, Aubinet M, Ceulemans R, Kowalski A, Vesala T, Rannik U, Berbigier P, Loustau D, Guomundsson J, Thorgeirsson H, Ibrom A, Morgenstern K, Clement R, Moncrieff J, Montagnani L, Minerbi S, Jarvis P (2000) Respiration as the main determinant of carbon balance in European forests. Nature 404:861-865

Venables WN, Ripley BD (2002) Modern applied statistics with S, 4th edn. Springer, New York

Xu L, Baldocchi D, Tang J (2004) How soil moisture, rain pulses, and growth alter the response of ecosystem respiration to temperature. Glob Biogeochem Cycles 18(4). doi:10.1029/2004GB002281

Zimov S, Davidov S, Voropaev Y, Prosiannikov S, Semiletov I, Chapin M, Chapin F (1996) Siberian $\mathrm{CO}_{2}$ efflux in winter as a $\mathrm{CO}_{2}$ source and cause of seasonality in atmospheric $\mathrm{CO}_{2}$. Clim Change 33(1):111-120 